\title{
Evidentiary Legerdemaim: Deciding When Daubert Should Apply to Social Science Evidence
}

\author{
Teresa S. Renaker†
}

A recent Supreme Court interpretation of Rule 702 of the Federal Rules of Evidence has resulted in an inconsistent application of the rule among lower courts. Rule 702 allows the introduction of expert testimony regarding scientific or other specialized knowledge to assist the trier of fact in understanding the evidence presented. The Supreme Court provided a test for the admissibility of "scientific" knowledge, but was silent as to "specialized" knowledge, resulting in confusion among some courts as to the difference between the two types of evidence. This Comment examines the Supreme Court's decision and its application in lower court opinions that followed. The author examines the function of specialized-knowledge testimony, which draws on the personal experience, training, and skills of the expert, and demonstrates how its admission can be beneficial as long as the expert does not draw explicit conclusions regarding the facts in issue. This Comment then focuses on the unique problems presented by expert psychological testimony that may tend to confuse or overawe the jury, or that may be of questionable scientific validity. The author presents a functional test that courts should use as an initial matter to distinguish between scientific and specialized knowledge. Once the evidence is categorized as scientific rather than specialized knowledge, only then should the Supreme Court's test for the admissibility of scientific knowledge apply.

\section{INTRODUCTION}

The Supreme Court's 1993 decision in Daubert v. Merrell Dow Pharmaceuticals ${ }^{1}$ defined a new standard for courts to use in determining the admissibility of scientific evidence under Rule 702 of

Copyright $\odot$ I996 California Law Review, Inc.

$\dagger$ Law clerk to the Honorable Irma E. Gonzalez, United States District Judge, Southern District of California. B.A. 1986, Mount Holyoke College; J.D. 1996, Boalt Hall School of Law. University of California, Berkeley. I thank Professor Eleanor Swift for her advice and guidance in the preparation of this Comment. I also thank the editors of the California Law Review for their insights and suggestions.

I. 509 U.S. 579 (1993). 
the Federal Rules of Evidence. Based on the language of Rule 702,2 which governs expert testimony on matters of "scientific, technical, or other specialized knowledge," the Court rejected the "general acceptance" standard of Frye v. United States" in favor of a "scientific validity" standard. The Daubert Court held that the term "scientific knowledge" in Rule 702 means an inference or assertion "derived by the scientific method,"4 and that federal judges must play a "gatekeeping" role, determining whether the reasoning or methodology underlying an expert's proposed testimony is scientifically valid before admitting or excluding the testimony. ${ }^{5}$

After some initial confusion anong courts and commentators, it now seems clear that Daubert will not be interpreted to apply to all expert testimony under Rule 702 , but only to expert testimony that conveys "scientific," as opposed to "technical[] or other specialized" knowledge. 6 Nonetheless, after the decision, some courts failed to distinguish scientific from nonscientific expert testimony, applying the scientific validity test to proffered testimony such as that of an auto mechanic $^{7}$ and a construction consultant. ${ }^{8}$

Perhaps such a failure to distinguish scientific from nonscientific testimony is not so difficult to understand, because Daubert gave lower courts no guidance on how this distinction should be drawn. The Court set forth a new test for admissibility, but did not explain how courts should identify the expert testimony to which the test applies. As one district judge has renarked, "Daubert does not explicitly define 'science,' it defines 'scientific.' ... [A]s judges, we will be called upon

2. Rule 702 provides that "[i]f scientific, technical, or other specialized knowlcdge will assist the trier of fact to understand the evidence or to determine a fact in issue, a witness qualified as an expert by knowledge, skill, experience, training, or education may testify thereto in the form of an opinion or otherwise." FED. R. EvID. 702.

3. 293 F. 1013, 1014 (D.C. Cir. 1923).

4. Daubert, 509 U.S. at 590.

5. Id. at 592-93.

6. See id. at 590 n.8; Edward J. Imwinkelried, The Next Step After Daubert: Developing a Similarly Epistemological Approach to Ensuring the Reliability of Nonscientific Expert Testimony, 15 CArdozo L. Rev. 2271, 2272-73 (1994). But see David L. Faigman, The Evidentiary Status of Social Science Under Daubert: Is It "Scientific," "Technical," or "Other" Knowledge?, 1 PsYchol. PuB. PoL'y \& L. 960, 979 (1995) [hereinafter Faigman, Evidentiary Status] (arguing that "Rule 702 does not establisl categories subject to alternative analyses. Instcad, Rule 702 contemplates a fluid analysis, with a preference for scientific knowledge when it is or should be available."); David $L$. Faigman, Mapping the Labyrinth of Scientific Evidence, 46 HASTINGS L.J. 555, 559 (1995) (stating that reading Daubert to apply only to "scientific" knowledge "displays a crabbed interpretation of the Court's opinion as well as a misconstruction of the principles underlying Rule 702").

7. Williams v. General Motors Corp., 639 So. 2d 275, 289-90 (La. Ct. App. 1994) (holding that the lower court erred by not excluding auto mechanic's testimony under Daubert).

8. Iacobelli Constr., Inc. v. County of Monroe, 32 F.3d 19, 25 (2d Cir. 1994) (reversing district court's application of Daubert test in rejecting a construction consultant's affidavit and holding that the district court failed to distinguisl between scicntific and merely teclinical expert testimony). 
not only to determine what particular scientific methodology is reliable, but also what is science?"'

Courts have applied the Daubert test to a wide variety of expert testimony, including proffered expert testimony on economics, ${ }^{10}$ posttraumatic stress disorder and repressed memory, ${ }^{11}$ and factors affecting the reliability of eyewitness testimony. ${ }^{12}$ Courts have declined to apply the Daubert scientific validity test to testimony regarding forensic document examination ${ }^{13}$ and real estate appraisal. ${ }^{14}$ Yet no principle has emerged for distinguishing scientific expert testimony from technical or specialized expert testimony in order to apply what the Court itself characterized as the test for the admissibility of "purportedly scientific evidence."15

Courts need a principled basis for distinguishing between scientific expert testimony that is subject to the Daubert test and technical or other specialized expert testimony that must simply "assist the trier of fact."16 In particular, courts need to know when testimony that would flunk the Daubert test may be admissible as specialized knowledge. Unlike testimony about teratology (the study of causes of birth defects) as in Daubert, ${ }^{17}$ which will always be treated as scientific knowledge, and testimony about law enforcement officers' observations of criminal be-

9. ABA Section of Science and Technology, Scientific Evidence Review, Monograph No. 2, at 104 (1994) (remarks of Judge Marilyn Hall Patel). Judge Patel continued, "We will, undoubtedly, be confronted with arguments that if a particular proffered does not meet the scientific knowledge criteria for reliability, that it's still admissible as specialized knowledge.... Does the 'specialized knowledge' term or provision in 702 provide an escape hatch for evidence which doesn't pass scientific muster?" Id. at 103-04; see also Michael H. Graham, FEDERAL PRACTICE AND Procedure $\S 6652$, at 34 (Supp. 1996) ("[T]here is no obvious clear demarcation between scientific knowledge and technical and other specialized knowledge.").

10. See Petruzzi's IGA Supermarkets, Inc. v. Darling-Delaware Co., 998 F.2d 1224, 1237-38 (3d Cir. 1993) (holding multiple regression analysis is a reliable scientific method under Daubert); In re Aluminum Phosphide Antitrust Litig., 893 F. Supp. 1497, 1505-07 (D. Kan. 1995) (mem.) (holding testimony of expert economist inadmissible under Daubert).

11. See Isely v. Capuchin Province, 877 F. Supp. 1055, 1057-67 (E.D. Micb. 1995) (holding testimony of expert psychologist on post-traumatic stress disorder and repressed memory admissible under Daubert).

12. See United States v. Brien, 59 F.3d 274, 274-78 (1st Cir.), cert. denied, 116 S. Ct. 401 (1995) (affirming district court's determination that psychologist's testimony on eyewitness identification was inadmissible under Daubert).

13. See United States v. Starzecpyzel, 880 F. Supp. 1027, 1036-50 (S.D.N.Y. 1995) (mem.) (finding testimony of forensic document examiner to be specialized knowledge-accordingly, Daubert did not apply, and the testimony was admissible; also noting that if Daubert did apply, testimony would be inadmissible).

14. See Hawthome Partners v. AT\&T Techs., Inc., No. 91 C 7167, 1993 WL 311916, at *4 (N.D. Ill. Aug. 11, 1993) (holding Daubert inapplicable because "[c]ommercial real estate appraisal is not a branch of social science").

15. Daubert, 509 U.S. at 589.

16. FeD. R. Evid. 702.

17. See infra Part $\mathrm{I}$. 
havior, ${ }^{18}$ which will always constitute specialized knowledge, some evidence from fields such as psychology can fit into either category depending on how the testimony functions.

This Comment uses the troublesome case of psychological syndrome evidence to develop a test for distinguishing scientific-knowledge testimony from specialized-knowledge testimony ${ }^{19}$ based on the function the evidence performs. Initially, commentators have posed the question of the applicability of the Daubert test on a field-by-field basis: "Are experts in such fields as psychology, economics, sociology, and political science testifying about 'scientific knowledge' so that the Daubert standard of admissibility applies?"20 I argue that rather than looking at the field that evidence comes from to determine whether by its nature the evidence is "scientific" or "specialized," courts must examine whether the specific testimony offered will serve a scientificknowledge purpose or a specialized-knowledge purpose. I propose that to preserve the integrity of the test for scientific evidence as a tool for ensuring that only scientifically valid testimony is admitted, courts should first determine whether proposed testimony functions as scientific or specialized knowledge, and only then assess its scientific validity or helpfulness.

Part I of this Comment describes the standard for admissibility of scientific expert testimony as set out in Daubert. Part II discusses the treatment of specialized-knowledge testimony, and attempts to draw a functional distinction between this testimony, which is subject only to the Rule 702 "helpfulness" test, and scientific-knowledge testimony, which must be both scientifically valid and helpful to the jury. Part III summarizes the special problems presented by expert testimony in the field of psychology, especially psychological syndrome evidence, that make courts' gatekeeping role especially difficult in this area. This Part describes the ways in which many courts after Daubert have distorted the test in order to admit as scientific evidence expert testimony that functions as specialized knowledge and should never have been subjected to the Daubert test in the first place.

Part IV describes a more uniform, regular, and principled approach to proposed expert testimony that appears to be "on the fence" between scientific and specialized knowledge. This approach involves a two-step inquiry. First, the court seeks to categorize proposed testimony as scientific or specialized knowledge by examining the function of the

18. See infra Part Il.

19. For the sake of brevity, I will refer to the category "technical or other specialized knowledge" as simply "specialized knowledge."

20. Margaret A. Berger, Evidentiary Framework, in Federal Judicial Center, Reference MANUAL ON SCIENTIFIC EvidENCE 37, 84 (1994) (citations omitted) (explaining that the question of the Daubert test's applicability to the social sciences is unresolved). 
proposed testimony. Having categorized the testimony, the court then applies the appropriate test to determine its admissibility. Part IV then proposes a possible solution to the categorization problem by examining how a functional test can provide a more principled basis for admitting or excluding expert testimony. It sets forth paradigms to illustrate the functional test and compares this approach with other commentators' views on this problematic evidentiary issue.

This Comment criticizes how some courts have approached the problem of categorizing expert testimony under Daubert. I do not attempt an independent assessment of the reliability of the various types of expert testimony that I describe as problematic. ${ }^{21}$ Instead, I hope to provide a clear definition of the problem of distinguishing between "scientific" knowledge and "technical[] or other specialized" knowledge for purposes of the applicability of the Daubert standard, to show why the approaches that some courts have taken to this problem thus far are inadequate and undermine the usefulness of the standard, and to propose an alternative approach that maintains the integrity and utility of the scientific validity standard.

\section{The Daubert Standard For AdMitTing SCIENTIFIC KNoWledge}

Courts' and commentators' focus on how Daubert affects evidence from the physical sciences is not surprising, since Daubert itself concerned animal studies, pharmacological studies, and reanalyses of epidemiological studies which purported to show that the anti-nausea drug Bendectin could have caused the plaintiffs' birth defects. ${ }^{22}$ The district court granted Merrell Dow's motion for summary judgment, concluding that the plaintiffs' evidence did not meet the "general acceptance" standard of Frye $v$. United States, which required that novel scientific evidence have gained "general acceptance in the particular field in which it belongs. ${ }^{23}$ The Ninth Circuit affirmed. ${ }^{24}$

The Supreme Court reversed, holding unanimously that Frye had been superseded by Rule 702 of the Federal Rules of Evidence. ${ }^{25}$ In a portion of the opinion joined by seven justices, the Court went on to promulgate a standard for screening proposed scientific evidence for relevance and reliability under Rule $702 .{ }^{26}$ The Court based its standard

21. Many other commentators have written cogently on the reliability of, for example, expert psychological testimony. For a brief summary of a few of their observations, see infra notes $87-103$ and accompanying text.

22. Daubert, 509 U.S. at 583.

23. Id. at 583 (internal quotations omitted).

24. Id. at 584 (citing Daubert v. Merrell Dow Pharm., lnc., 951 F.2d 1128 (9th Cir. 1991)).

25. Id. at 587, 597-98.

26. Id. at $589-92$. 
on the language of Rule 702, explaining that "'scientific' implies a grounding in the methods and procedures of science," while "'knowledge' connotes more than subjective belief or unsupported speculation."27 Thus, "in order to qualify as 'scientific knowledge,' an inference or assertion must be derived by the scientific method" and must be "supported by appropriate validation."28 Furthermore, the condition that expert testimony "assist the trier of fact" imposes a requirement of relevance or "fit" with the issues in the case: the proponent must show "a valid scientific connection to the pertinent inquiry."29 The Court expressly excluded "technical, or other specialized knowledge" froin its discussion. ${ }^{30}$

Finally, the Court offered "some general observations" of factors that should bear on a federal judge's inquiry into the scientific validity of proposed testimony. ${ }^{31}$ First, whether a theory or technique "can be (and has been) tested" is a "key question." ${ }^{32}$ A second consideration is whether the theory or technique has been the subject of peer review and publication. In the case of a "particular scientific technique," a court should also consider the "known or potential rate of error" and the "existence and maintenance of standards controlling the technique's operation." ${ }^{33}$ Lastly, "general acceptance" remains a factor. ${ }^{34}$ The Court also noted one final distinction between the standard of Rule 702 and that of Frye: while the Frye decision focused exclusively on "novel" scientific techniques, the application of Rule 702 is not confined to "unconventional evidence." 35

Chief Justice Rehnquist, joined by Justice Stevens, agreed that the Frye rule had not survived the adoption of the Federal Rules of Evidence. ${ }^{36}$ But they dissented from the Court's construction of Rule 702 and from its reasoning, which they criticized as "vague and abstract." ${ }^{37}$ The dissent questioned the majority's focus on the words "scientific knowledge," inquiring,

[w] hat is the difference between scientific knowledge and technical knowledge; does Rule 702 actually contemplate that the phrase "scientific, technical, or other specialized knowledge" be broken down into numerous subspecies of expertise, or did its

27. Id. at 590 .

28. Id.

29. Id. at 591-92.

30. Id. at $590 \mathrm{n} .8$.

31. Id. at 593 .

32. Id.

33. Id. at 594 .

34. Id.

35. Id. at 592 n.11.

36. Id at 598 (Rehnquist, C.J., concurring in part and dissenting in part).

37. Id. 
authors simply pick general descriptive language covering the sort of expert testimony which courts have customarily received? $?^{38}$

In the three years since the Daubert decision, it has become very clear that it is precisely this question of the difference between scientific and technical or specialized knowledge that has confounded courts attempting to assess the admissibility of psychological syndrome evidence and other social science evidence after Daubert.

On remand, the Ninth Circuit elected to consider factors more deferential to the scientific community ${ }^{39}$ The court of appeals was skeptical of federal judges' ability to undertake the "daunting task" of resolving "disputes among respected, well-credentialed scientists about matters squarely within their expertise." "[O]ffering guidance on the application of the Daubert standard in this circuit," ${ }^{, 41}$ the court crafted its own set of factors, which differ from the four set out by the Supreme Court. According to the Ninth Circuit, the most persuasive proof of scientific validity is " $[t]$ hat the testimony proffered by an expert is based directly on legitimate, preexisting research unrelated to the litigation." ${ }^{\text {"42 }}$ Peer review and publication, also factors for the Supreme Court, provide a second means to prove scientific validity. ${ }^{43}$ Absent these factors, under the Ninth Circuit's view, experts must be able to "explain precisely" how they arrived at their conclusions and "point to some objective source-a learned treatise, the policy statement of a professional association, a published article in a reputable scientific journal or the liketo show that they have followed the scientific method, as it is practiced by (at least) a recoguized minority of scientists in their field."14

On the basis of these factors, the court rejected the evidence of one of the plaintiffs' experts. ${ }^{45}$ This expert, Dr. Palmer, was the only one of the plaintiffs' experts who was willing to testify that Bendectin had caused each of the children's limb defects. His affidavit stated only that Bendectin is a teratogen and that he had examined the plaintiffs' medical records. He offered "no tested or testable theory to explain how, from this limited information, he was able to eliminate all other potential causes of birth defects.... 'Indeed, no understandable scientific basis

38. Id. at 600 .

39. Daubert v. Merrell Dow Pharm., Inc., 43 F.3d 1311 (9th Cir.) (Daubert II), cert. denied, 116 S. Ct. 189 (1995). The Ninth Circuit affirmed the district court's original grant of summary judgment, declining to remand the case to the district court. Id. at 1315.

40. Id. at 1315-16.

4I. Id. at 1315 .

42. Id. at 1317 .

43. Id. at 1318 .

44. Id. at 1319.

45. Id. 
is stated. Personal opinion, not science, is testifying here." "46 Thus, although the Ninth Circuit articulated its own reliability factors of independent research, peer review and publication, and "objective support," Dr. Palmer's testimony ultimately was inadmissible not because of the absence of these factors but because he failed to identify a testable hypothesis underlying his conclusions.

Dr. Palmer's was the only proposed testimony to which the Ninth Circuit actually applied the reliability test on remand. It rejected the remainder of the proffered testimony on the ground that because it did not show the degree of probability of causation required by California tort law, it failed to meet even the less stringent "fit" requirement. ${ }^{47}$ Thus, the court rejected this expert testimony not because the underlying explanative theory did not represent scientific lnowledge, but because it did not even claim to explain enough to make it relevant. The Supreme Court had treated the proposed testimony as though the experts would be able to testify that their techniques-animal studies, pharmacological studies, and reanalyses of epidemiological studiesshowed that Bendectin had caused the plaintiffs' birth defects. ${ }^{48}$ The Ninth Circuit again affirmed the grant of summary judgment for Merrell Dow because the experts would only claim that Bendectin was "capable of causing birth defects," the issue in the case.

\section{II}

\section{The Function of Specialized-Knowledge Testimony}

At the same time that the debate over "junk science"so has focused attention on the reliability of expert testimony in the sciences, little attention has been paid to the question of the reliability of specializedknowledge evidence. ${ }^{51}$ Under Rule 702 , specialized-knowledge testimony must be presented by a qualified expert and inust be knowledge that will assist the jury to determine a fact in issue. Some specializedknowledge expert testimony, such as that in the Johnson and Locascio

46. Id. (quoting Turpin v. Merrell Dow Pharm., Inc., 959 F.2d 1349, 1360 (6th Cir. 1992) (also rejecting testimony by Dr. Palmer)).

47. Id. at $1320-22$.

48. Daubert, 509 U.S. at 583-84.

49. Daubert II, 43 F.3d at 1321.

50. See Peter W. Huber, Galileo's Revenge: Junk Science in the Courtroom 2 (1991) (using term "junk science" to refer to "elaborate, systematized, jargon-filled, serious-sounding deceptions" presented in court and attributing genesis of term to trial lawyers).

51. See Imwinkelried, supra note 6, at 2273. But see Lisa R. Askowitz \& Michael H. Graham, The Reliability of Expert Psychological Testimony in Child Sexual Abuse Prosecutions, 15 CaRdozo L. REv. 2027, 2099-2100 (1994) (proposing factors for assessing reliability of expert psychological testimony as specialized knowledge). 
cases discussed below, ${ }^{52}$ offers only background information without an explicit opinion on an issue in the case. Other testimony, such as that in the Markum and Chappell cases also discussed below, ${ }^{53}$ involves background information as well as an explicit conclusion regarding the events at issue..$^{54}$

In this section, I will show how the specialized-knowledge expert draws on personal experience, training, and skills. The expert may give background information that assists the jury in understanding the facts of the case, or may actually compare the facts to his or her experience. For example, in the post-Daubert case of United States $v$. Johnson, ${ }^{55}$ the Eighth Circuit ruled that the district court had properly admitted the testimony of an unindicted coconspirator, Keith Johnson, as an expert on gang activities and the business of drug trafficking. The defendants were convicted of conspiring to possess cocaine with the intent to distribute it and of knowingly engaging in a continuing criminal enterprise. ${ }^{56}$ Johnson was qualified as an expert on drug trafficking based on six years spent setting up drug distribution centers in different cities. ${ }^{57}$ The court held that this specialized knowledge was helpful to the jury:

In a drug distribution conspiracy trial, as we have here, a jury is presented with voluminous facts connecting the defendants and their alleged "conspiracy-related" activities. To understand these connections and their relationship, it is "helpful" for the jury to understand how drug distribution rings are organized and how the various associations between the members are initiated and maintained..$^{58}$

Thus, Johnson's testimony apparently gave background information only and left the jury to draw its own comparisons between Johnson's

52. See discussion infra notes 55-63 and accompanying text.

53. See discussion infra notes 64-76 and accompanying text.

54. The four examples all involve criminal prosecutions. However, specialized-knowledge testimony also plays a role in civil trials. In civil trials, specialized-knowledge testimony is often involved in calculating damages or establishing the standard of practice in a profession. See Hawthome Partners v. AT\&T Techs., Inc., No. 91 C 7167, 1993 WL 311916 (N.D. III. Aug. 11, 1993).

Interestingly, courts vary in characterizing expert testimony by economists, which asually arises in civil trials, as scientific knowledge or specialized knowiedge. In Petruzzi's IGA Supermarkets, Inc. v. Darling-Delaware Co., 998 F.2d 1224, 1237-38 (3d Cir. 1993), the Third Circuit, citing Daubert, held that multiple regression analysis used by an economist was a reliable scientific method. But in Liu v. Korean Air Lines Co., No. 84 Civ. 0690 (PNL), 1993 WL 478343, at *1 (S.D.N.Y. Nov. 16,1993 ), the district court ruled that the testimony of an economist on the projected growth of the Taiwanese economy was admissible as specialized knowledge (although part of his testimony was excluded).

55. 28 F.3d 1487 (8th Cir. 1994), cert. denied, 115 S. Ct. 768, and cert. denied sub nom., Scott v. United States, 115 S. Ct. 1263 (1995).

56. Id. at 1492 .

57. Id. at 1496.

58. Id. at 1497 n. 10 . 
experience in the drug trade and the evidence regarding the defendants' conduct.

In United States v. Locascio, ${ }^{59}$ another post-Daubert case, the Second Circuit held that there was no manifest error in admitting the expert testimony of an FBI agent on "the nature and function of organized crime families," including their structure, rules, and jargon. ${ }^{60}$ The agent was qualified as an expert on organized crime based on his experience with the FBI's Organized Crime Program. ${ }^{61}$ The court stated the applicable test for helpfulness as "whether the untrained layman would be qualified to determine intelligently and to the best possible degree the particular issue without enlightenment from those having a specialized understanding of the subject involved in the dispute." Applying this test, the court concluded that it was reasonable to assume that jurors are "not well versed in the structure and methods of organized crime families." ${ }^{33}$ Thus, the testimony in Locascio apparently also functioned only as background information to which the jury could draw comparisons.

In other cases involving specialized-knowledge testimony, the expert states an opinion about an issue in the case. For example, in United States v. Markum, ${ }^{64}$ the Tenth Circuit held that a fire chief's expert testimony was properly admitted regarding whether an arson had been committed. The defendant was convicted of conspiracy to commit arson. ${ }^{65}$ A house owned by the defendant had been destroyed by the second of two fires there on the same night. The fire department extinguished the first fire at the house, taking precautions to ensure it would not rekindle. Nonetheless, an hour after the firefighters left the scene, they were recalled to find the house engulfed in flames that burned it to the ground. ${ }^{66}$ The fire chief who responded to both fires testified as an expert at the trial that "he had seen fires rekindle, but never in such a short time or so completely," and that "a quick and devastating rekindling is extremely rare because a house is soaked with water in the process of extinguishing the original fire." ${ }^{67}$ He gave his opinion that the second fire was not a rekindling of the first and that it had been deliberately set. ${ }^{68}$ The Tenth Circuit reviewed the chief's

59. 6 F.3d 924 (2d Cir. 1993), cert. denied sub nom., Gotti v. United States, 114 S. C. 1645 (1994).

60. Id. at $936-37,939$.

61. Id. at 937.

62. Id. at 936 (quoting FeD. R. Evid. 702 advisory committee's note).

63. Id. at 937.

64. 4 F.3d 891 (10th Cir. 1993).

65. Id. at 893.

66. Id. at 894 .

67. Id.

68. Id. at 894,896 . 
qualificatious and the helpfulness of his testimony to the jury. He had been a firefighter for twenty-nine years, "observing and extinguishing fires throughout that period," and had "attended arson schools and received arson investigation training." As to helpfulness, which the court, following Daubert, construed as "go[ing] primarily to relevance, $" 70$ the court concluded that

[t] he very fact that fire departments have specialized arson investigation units argues that arson is an area of technical and specialized knowledge that goes beyond the ken of the average juror. Whether the second fire was the result of arson was a factual question highly relevant to the case and properly addressed by expert testimony. Chief Pearson did not opine that Markum set the fire, but only that someone deliberately set it. ${ }^{71}$

Thus, the fire chief in Markum gave testimony that described his experience with fires rekindling, compared that experience to his observations of the second fire, and offered a couclusion based on that comparison. He did not purport to apply an objective theory, such as "rekindled fires do not burn down houses within one hour." Rather, he offered a subjective comparisou informed by his experience and training and based on his impressions of the thoroughness with which the first fire was extinguished and the ferocity of the second fire.

Similarly, in United States v. Chappell, ${ }^{72}$ the court of appeals held that a security officer's testimony was properly admitted as expert testimony in a prosecution for counterfeiting. The witness, an assistant security officer of the bank on which the counterfeit checks had been drawn, testified as an expert in the field of detecting counterfeit checks. ${ }^{73}$ He stated that "irregularities in the checks, such as inaccurate routing and account numbers, incorrect electronic coding, and absence of perforation, identified them as forgeries." ${ }^{274}$ The defendant protested that "detecting counterfeit checks' does not constitute a proper field of expertise and that, in any event, [the witness's] training as a bank security officer did not qualify him as an expert."75 However, the court of appeals concluded that the testimony was proper because the security officer's "years of experience afforded specialized knowledge permit-

69. Id. at 896 .

70. Id.

71. Id.

72. 6 F.3d 1095 (5th Cir. 1993), cert. denied sub nom., Mitchem v. United States, 510 U.S. 1183 (1994), and cert. denied sub nom., Shephard v. United States, 510 U.S. 1184 (1994).

73. Id. at $1097,1100$.

74. Id. at 1100 .

75. Id. 
ting him to assist the jury in evaluating the genuineness of the documents." 76

As in Markum, in Chappell the expert called on his experience with counterfeit checks to draw the jury's attention to features of the checks that gave rise to his opinion. Presumably, he testified to the effect that "all our bank's checks come in books, so they have perforations," and "we have never printed a check with both the wrong account number and the wrong routing number on it," and stated his opinion that the checks were counterfeit.

These cases demonstrate that even when the expert states an opinion, courts find in effect that testimony characterized as specialized knowledge involves the application not of an explanative theory but of a "helpful practical skill derived from ... training and experience." contrast to this "purely practical" expertise, ${ }^{78}$ an expert witness testifying to scientific knowledge provides theoretical expertise. The scientific-knowledge expert applies an explanative theory to draw a conclusion about facts in the case, to "predict back"79 from an outcome to determine causation.

I posit that some expert testimony, particularly in social sciences such as psychology, can fall into either category. Some testimony by psychologists resembles the testimony of the FBI agent in Locascio or the fire chief in Markum, while other testimony by psychologists more closely resembles that of the teratologist in Daubert. Indeed, proffered testimony by experts in psychology and other fields often contains elements of both types of testimony. In Part III, I demonstrate that a common approach for courts has been to characterize psychological testimony as science and apply Daubert, but admit only portions of the evidence that amount to specialized knowledge. I argue that this approach undermines the "scientific validity" standard. In Part IV, I describe a case in which the court took the better approach of rejecting purportedly scientific testimony under Daubert, then assessing the helpfulness of its nonscientific claims and admitting them as specialized knowledge. This approach avoids the unpredictable criteria and inconsistent results that obtain when courts try to assess testimony that functions as specialized knowledge under a rubric designed for scientific evidence.

76. Id.

77. United States v. Starzecpyzel, 880 F. Supp. 1027, 1048 (S.D.N.Y. 1995).

78. Id. at 1048.

79. State v. Alberico, 861 P.2d 192, 210 (N.M. 1993) (describing trial court's objection to idea that psychologist can "predict back" from observed symptoms to cause of symptoms). 
III

Special Problems of Expert Psychological Testimony

\section{A. Factors Affecting the Admissibility of Expert Psychological Testimony}

\section{The Issue of "Truthfulness" Determinations}

Courts have long distrusted any claims of science to be able to determine whether a witness is telling the truth. Indeed, the long-lived "general acceptance" standard of Frye v. United States arose in the context of the admissibility of expert testimony offered by a defendant in a murder trial on the results of the "systolic blood pressure deception test," a precursor of the polygraph. The Frye court described the evidence as based on "the theory ... that truth is spontaneous, and comes without conscious effort, while the utterance of a falsehood requires a conscious effort, which is reflected in the blood pressure." 180 Finding that the test had not yet gained "general acceptance... among physiological and psychological authorities," the court affirmed the exclusion of the evidence and upheld the defendant's conviction. ${ }^{81}$ This fundamental distrust of explanative theories that purport to establish whether a person is telling the truth underlies courts' approaches to expert psychological testimony today. Perceiving credibility assessments to be peculiarly the task of the jury, courts are extremely wary of any testimony that substitutes the expert's judgment for that of the jury conceruing witness credibility, or otherwise "invades the province of the jury." 82

This skeptical stance regarding "scientific" assessments of truthfulness collides in sexual abuse cases with a powerful desire for corroboration of victims' claims. Rarely are there witnesses to the alleged abuse or other evidence beyond the testimony of the victim regarding what occurred. The victim may be a child and may have given conflicting accounts of the abuse or even recanted his or her initial report. Prosecutors, victims, and parties to civil actions are eager for ways to validate the victim's testimony objectively, and turn to theories such as

80. Frye v. United States, 293 F. 1013, 1014 (D.C. Cir. 1923).

81. Id.

82. Interestingly, some courts reassessing the admissibility of polygraph evidence under Daubert have held it admissible under certain circumstances. Compare United States v. Crumby, 895 F. Supp. 1354, 1358-61 (D. Ariz. 1995) (finding polygraph evidence admissible because, among other factors, it is generally accepted in the relevant scientific community, namely among polygraphers) and United States v. Galbreth, 908 F. Supp. 877, 890-93 (D. N.M. 1995) (providing comprehensive analysis of theory of polygraphy and finding polygraph evidence admissable under Daubert) with United States v. Dominguez, 902 F. Supp. 737, 739 (S.D. Tex. 1995) (finding polygraph evidence unreliable because of "the subjectivity of the procedures involved"). 
child sexual abuse accommodation syndrome (CSAAS) ${ }^{83}$ and posttraumatic stress disorder (PTSD), ${ }^{84}$ offered to explain the behavior of victims, plaintiffs, and defendants.

Some experts in psychology and other fields are prepared to claim that their techniques can "diagnose" abuse. Yet courts remain largely unreceptive to testimony that appears to function only to "bolster" or "vouch for" the credibility of the victim. For example, in the preDaubert case of United States v. Azure, ${ }^{85}$ admission of a pediatrician's testimony that in his opmion the victim was telling the truth about having been sexually abused was reversible error. Another opinion drew the Frye analogy explicitly, stating that "[t]he jury is the lie detector in the courtroom and is the only proper entity to perform the ultimate function of every trial-determination of the truth." ${ }^{.86}$

Another controversial area of psychological evidence that implicates some of the same concerns deals with research into the reliability of eyewitness identification. ${ }^{87}$ Again, a prosecution or a civil suit may depend on the accuracy of an identification made by an eyewitness who saw the person identified only briefly, who is of a different race than the person identified, who made an identification after a substantial passage of time, and so on ${ }^{88}$ Expert testimony may help the jury better assess the accuracy of an identification. At the same time, though, courts question whether testimony on factors affecting the accuracy of identifications amounts to impermissible commentary on the credibility of the eyewitness. ${ }^{89}$

83. See, e.g., State v. Foret, 628 So. 2d 1116, 1123-27 (La. 1993) (holding inadmissable child psychologist's testimony using dynamics of CSAAS to diagnose whether abuse had occurred).

84. See, e.g., Alberico, 861 P.2d at 206-12 (holding admissable evidence of post-traumatic stress disorder of aileged child sexual abuse victim). Professor Falk points to the recognition of PTSD by the American Psychiatric Association as a tuming point in the study of mental illness brought on by "environmental stressors." Patricia J. Falk, Novel Theories of Criminal Defense Based upon the Toxicity of the Social Environment: Urban Psychosis, Television Intoxication, and Black Rage, 74 N.C. L. REv. 731, 736 (1996) (discussing social science research).

85. 801 F.2d 336, 339-41 (8th Cir. 1986).

86. State v. Chul Yun Kim, 350 S.E.2d 347, 351 (N.C. 1986) (quoted in Foret, 628 So. $2 d$ at 1128).

87. See, e.g., United States v. Rincon (Rincon II), 28 F.3d 921, 923-26 (9th Cir.), cert. denied, 115 S. Ct. 605, (1994) (excluding under Daubert expert testimony on reliability of eyewitness identification testimony); United States v. Gates, 20 F.3d 1550 (11th Cir. 1994) (remanding for reconsideration under Daubert); United States v. Amador-Galvan, 9 F.3d 1414, 1418 (9th Cir. 1993) (same); United States v. Garcia, 40 M.J. 533, 536-37 (A.F.C.M.R. 1994), review granted in part, 42 M.J. 414 (C.A.A.F. 1995), and aff'd, 44 M.J. 27 (C.A.A.F. 1996) (admitting under Daubert).

88. See Saul M. Kassin et al., The "General Acceptance" of Psychological Research on Eyewitness Testimony: A Survey of the Experts, 44 AM. Psychologist 1089, 1095 (1989) (discussing experts' assessments of the reliability of research on the effects of exposure time, cross-racial identification bias among white witnesses, and "the forgetting curve").

89. See, e.g., United States v. Brien, 59 F.3d 274, 276 (1st Cir.), cert. denied, 116 S. Ct. 401 (1995) ("[T]he expert testimony in this case involved a credibility determination within the ken of the ordinary judge and juror-unlike, say, DNA identification."). 


\section{The Issue of Overawing or Confusing the Jury}

In addition to this concern with truthfulness determinations, when evidence based on psychology is characterized as scientific evidence it engages the concern that evidence presented as scientific carries an "aura of infallibility" that will lead the jury to abdicate its role of deciding the facts in favor of reaching the result that the scientific testimony seems to dictate. As one court wrote, "[t]he problem is that most lay people, including the jury, are likely to feel... that the expert is better qualified to draw the inference... and therefore defer to the expert. The law should guard against such deference unless there is substantial basis for it." "90 The argument that expert testimony overwhelms the jury also implicates Rule 403, which allows courts to exclude evidence that will confuse the issues or mislead the jury. ${ }^{91}$ A related concern is that jurors confronted with scientific evidence, rather than deferring to it, will be so confused that they will decide the issues on improper bases." ${ }^{92}$ Cases involving a "battle of the experts," in which each side presents highly technical expert opinion supporting its position, bring this concern to the fore.

Some courts and commentators dispute the view that scientific evidence overwhelms the jury. Professor Dreyfuss rejects the "overwhelmingness" argnment on the grounds that laypeople's everyday exposure to science, including changes and reversals in scientific opinion, has increased substantially since Frye was decided. She argues that juries are not so much overwhelmed by scientific evidence as confused by inadequate or illogical presentation. ${ }^{93}$ In particular, the idea that juries are unduly impressed with psychological evidence seems questionable. As Professor McCord observes,

[t]he essence of such "soft" psychological evidence is not locked up in soine mysterious nonhuman device or process, and the expert on the stand can be grilled regarding the foibles of psychological research. Further, and perhaps more important, most jurors do not conceive of psychological research as very, if at all, "scientific." It is not likely to elicit unquestioning juror acceptance. ${ }^{94}$

90. State v. Alberico, 861 P.2d 192, 199 (N.M. 1993) (quoting State v. Alberico, 816 P.2d 219 (N.M. Ct. App. 1991)) (internal quotation marks omitted) (emphasis in original).

91. See Daubert, 509 U.S. at 595; Berger, supra note 20, at 115.

92. See Rochelle Cooper Dreyfuss, Is Science a Special Case? The Admissibility of Scientific Evidence After Daubert v. Merrell Dow, 73 Tex. L. REv. 1779, 1796-97 (describing the argument that "[l]acking the technical expertise to examine scientific claims critically, jurors may find for the side with the most experts, the most presentable experts, or the prettiest charts").

93. Id. at $1798-1800$.

94. David McCord, Syndromes, Profiles and Other Mental Exotica: A New Approach to the Admissibility of Nontraditional Psychological Evidence in Criminal Cases, 66 OR. L. REv. 19, 85-86 (1987). 
Similarly, the New Mexico Supreme Court rejected a lower court's "premise that juries are awed" by expert psychological testimony, citing several cases in which juries apparently rejected expert testimony on the issue of sanity. ${ }^{95}$

The extent to which proffered expert testimony implicates these concerns about truthfulness determinations and scientific "overwhelmingness" is a key factor in determining whether the testimony should be characterized as scientific- or specialized-knowledge evidence. ${ }^{96}$ Under my theory, to the extent that expert testimony raises these issues, it does so when it functions like scientific evidence-when it offers the jury a purportedly valid theory to apply to the facts of the case. Testimony that offers the jury an account of experience, observations, or skill to which it can compare the facts of the case does not engage these concerns to the same degree.

\section{Scientific Validity}

The scientific validity of psychological expert testimony has been attacked by both legal and social science scholars. The purpose of this Comment is not to contribute to this debate, but a very brief overview is useful in understanding the cases. Syndrome evidence in particular is criticized as having an insufficient empirical basis, at least for some purposes. ${ }^{97}$ Syndrome descriptions may be useful in planning treatment but have little value in diagnosing the cause of the symptoms. ${ }^{98}$ For example, critics point out that in psychology "the matter of primary clinical significance" is how the patient feels rather than establishing objectively what the patient's experiences have been. Thus, a treating psychologist's primary concern in working with a child who may have been sexually abused is whether the child "honestly feels abused." Critics question the role of this judgment in the legal inquiry into whether a defendant has committed the offense of child abuse. ${ }^{100}$

Critics also question the scientific basis of syndrome testimony, noting that many syndrome "symptoms" may be just as common among non-victims of, for example, sexual abuse, as they are among

95. Alberico, 861 P.2d at 200.

96. See Berger, supra note 20 , at 85 (arguing that the debate over whether "hard" and "soft" scientific evidence should be subjected to the same level of scrutiny turns on one's assessment of the risk that jurors will be "swayed by worthless social science evidence").

97. See Askowitz \& Graham, supra note 51, at 2085-87; Gary B. Melton \& Susan Limber, Psychologists' Involvement in Cases of Child Maltreatment: Limits of Role and Expertise, 44 AM. PSYCHOLOGIST 1225, 1229 (1989).

98. See Askowitz \& Graham, supra note 51, at 2038; Melton \& Limber, supra note 97, at 1229.

99. Melton \& Limber, supra note 97 , at 1229.

100. See Melton \& Limber, supra note 97, at 1229; see generally David Faust \& Jay Ziskin, The Expert Witness in Psychology and Psychiatry, SCIENCE, July 1988, at 31 (disussing the limited reliability of clinicians' judgments in such contexts). 
victims. ${ }^{101}$ Research into the reliability of eyewitness identification has also been criticized as relying on unrepresentative samples, often groups of college students. ${ }^{102}$ Fundamentally, these theories are not subject to the kind of empirical verification traditionally associated with the scientific method, because it is impossible to conduct controlled experiments involving situations such as child sexual abuse or bank robberies. ${ }^{103}$

The following section shows how courts have dealt with these problems under Daubert and fashioned an alternative specializedknowledge function for psychological syndrome evidence. These courts exclude testimony that makes unsupported scientific claims while admitting testimony that functions like specialized knowledge, describing clinical observations and anecdotal evidence. However, because these courts continue to characterize the testimony as scientific evidence and conclude that it meets the scientific-validity standard, the decisions threaten to render that standard meaningless.

\section{B. Expert Psychological Testimony After Daubert}

In a series of cases beginning shortly after the Daubert decision, a number of federal and state courts have addressed the question of the admissibility of psychological syndrome evidence under Daubert. These courts have held, in effect, that psychological evidence in sexual abuse cases is admissible for what I term a "specialized-knowledge purpose": experts are permitted to testify to experience, observation, and skill. But psychological evidence is inadmissible for a "scientificknowledge purpose": experts are not permitted to offer evidence in the form of explanative theories. These courts conclude that an expert testifying about a victim's psychological symptoms may not give an opinion about the victim's truthfulness, the cause of the symptoms, or whether the alleged abuse occurred. ${ }^{104}$ However, courts have generally

101. See Melton \& Limber, supra note 97, at 1229; see also Askowitz \& Graham, supra note 51, at 2085-86; David L. Faigman, To Have or Have Not: Assessing the Value of Social Science to the Law as Science and Policy, 38 EMORY L.J. 1005, 1060-62 (1989).

102. See Faigman, supra note 101, at 1028, 1056.

103. See Askowitz \& Graham, supra note 51, at 2079 ("it is virtually impossible to test theories of child sexual abuse under controlled conditions"); Faigman, supra note 101, at 1013 (coining phrase "suppositional science" to describe untested or untestable social science findings); see also JoHN Ziman, Reliable KNowledge: An Exploration of the Grounds for Belief in Science 16668 (1978) (discussing experimental simplification in social science and concluding that, unlike in the physical sciences, in social science, experimental simplification may make experimental findings irrelevant). Professor Faigman argues that courts should balance the necessity for expert testimony against the reliability of the science available to support it. Faigman, supra note 6, at 564-78. Where a social phenomenon is not susceptible to study by the scientific method, judges should "demand the best science available and remain aware of its limitations." Id. at 561.

104. See Isely v. Capuchin Province, 877 F. Supp. 1055, 1067 (E.D. Mich. 1995) (holding that psychologist could not testify that she believed plaintiff or that she believed the alleged incidents occurred); Gier v. Educational Serv. Unit No. 16, 845 F. Supp. 1342, 1353 (D. Neb. 1994), aff'd, 66 
allowed experts to describe the typical symptoms or behaviors of known victims, describe the symptoms or behaviors observed in the victim in the case, and testify to an opinion that the victim's symptoms or behaviors are "consistent with" those of known victims. ${ }^{105}$

Thus, psychological experts may not claim for their techniques the capacity to diagnose or "predict back,"106 to determine what events caused the psychological symptoms-a scientific-knowledge use. However, psychological experts may offer background information and a comparison, based on their experience and the collective knowledge of their discipline, between the symptoms of known sexual-abuse survivors and the symptoms observed in the victim or victims in the case-a specialized-knowledge use. This latter use of psychological evidence resembles the testimony of specialized-knowledge experts such as the FBI agent in Locascio. The court permits the expert to testify to his or her experience or training and to his or her observations of the events or individuals in the case.

The first court to apply Daubert to psychological syndrome evidence was the New Mexico Supreme Court in State v. Alberico, ${ }^{107}$ which consolidated review of sexual abuse convictions involving defendants Marquez and Alberico. ${ }^{108}$ The same clinical psychologist, Dr. Lenssen, testified in both cases. Regarding Alberico, she testified that her evaluation of the victim was based on the diagnostic criteria for PTSD set out in the American Psychiatric Association's Diagnostic \& Statistical Manual of Mental Disorders (DSM III-R), and that she had determined that the victim suffered from PTSD "consistent with someone who suffered from sexual abuse or rape."109 Regarding Marquez, the trial court

F.3d 940 (8th Cir. 1995) (holding that psychologists could not testify that plaintiffs had been abused); State v. Foret, 628 So. 2d 1116, 1130-31 (La. 1993) (reversing conviction where psychologist testified to opinion that victim was telling the truth and that the victim had been sexually abused); State v. Fairweather, 863 P.2d 1077, 1081, 1085 (N.M. 1993) (reversing conviction where psychologist testified that victims were telhing the truth); State v. Lucero, 863 P.2d 1071, 1075, 1077 (N.M. 1993) (reversing conviction where psychologist testified that sexual molestation was cause of victim's PTSD, named the perpetrator, and testified to victim's credibihty); State v. Alberico, 861 P.2d 192, 210-12 (N.M. 1993) (holding that experts may not testify to victim's truthfulness, to cause of symptoms, or to identity of abuser).

105. See Iseley, 877 F. Supp. at 1067 (permitting psychologist to testify to her theories and opinions about PTSD and repressed memory and to her opinion as to whether plaintiff's behavior was consistent with that of people with PTSD and repressed memory and consistent with that of people who have been abused); Gier, 845 F. Supp. at 1353 (permitting psychologists in case involving mentally retarded plaintiffs to testify to behavior of non-retarded abused children and to observations that plaintiffs' behavior was consistent with that of non-retarded abused children); Alberico, 861 P.2d at 210 (holding that experts may testify that victim's PTSD symptoms are consistent with sexual abuse).

106. Alberico, 861 P.2d at 210.

107. 861 P.2d 192 (N.M. 1993).

108. Id. at $194 \mathrm{n} .1$.

109. Id. at 195. 
held a hearing on the admissibility of PTSD testimony. Dr. Lenssen and another state expert testified that it was common to use diagnostic categories from the DSM III-R in court, such as on issues of competency or sanity, and that psychologists look for internal consistency in their patients' accounts, which adds to reliability. A defense expert argued that clinical diagnoses may not be relevant to legal determinations and that psychologists base their diagnoses on the patient's accounts, rather than on a determination of whether the patient is telling the truth. All three experts agreed that because different stressors result in different PTSD symptoms, it was possible to pinpoint the cause of PTSD in a particular patient. ${ }^{110}$

One prosecution expert at the Marquez trial testified that the victim exhibited PTSD symptoms consistent with sexual abuse by her stepfather, the defendant. The other testified that the victim suffered from PTSD and that the symptoms could be traced to sexual abuse, and gave her opinion that the victim was not lying. ${ }^{111}$ The court of appeals overturned both convictions on the ground that the experts' testimony should not have been admitted on the issue of the cause of the victims' symptoms. ${ }^{112}$ The New Mexico Supreme Court remstated Alberico's conviction and affirmed the reversal of Marquez's, because while the Alberico expert had opined only that the victim suffered from PTSD consistent with having been sexually abused, the Marquez experts had also stated that the victim's symptoms were consistent with having been abused by the defendant and that they believed the victim was telling the truth. ${ }^{113}$

The Alberico court rejected the Frye standard for assessing admissibility under New Mexico's Rule 702. ${ }^{114}$ However, the court provided its own factors for assessing scientific validity. These included "tlie technique's relationship with established scientific analysis," "[ $t]$ he availability of specialized hterature addressing the validity of the techmique," and general acceptance. ${ }^{115}$ By ignoring testability and error rate, the court was able to find testimony regarding PTSD admissible because the disorder is listed in the DSM III-R, an example of "specialized literature." This fact indicated to the court that PTSD was generally accepted and had been "exposed to objective scientific scru-

110. Id. at 196.

111. Id. at 197.

112. Id. at 194, 198.

113. Id. at $195,212$.

114. Id. at 203 (citing Daubert, 509 U.S. at 579-80; United States v. Downing, 753 F.2d 1224, 1238-39 (3d Cir. 1985)).

115. Id. at 203-04. 
tiny and empirical verification."116 The court also accepted the experts' testimony that psychologists could identify the cause of PTSD. ${ }^{117}$ Yet, in spite of this liberal attitude toward the scientific validity of PTSD as a diagnostic tool, the court rejected the use of the PTSD diagnosis as a forensic tool to support testimony that the victim is telling the truth or that the defendant is responsible. ${ }^{118}$ As the same court subsequently explained, it had found that "[t]he psychologist has no scientifically valid or reliable means by which to determine whether a particular event has in fact happened." I1 It ruled that psychological experts may explain PTSD and offer an opinion that the victim's symptoms are consistent with it, ${ }^{120}$ but may not state that the victim is telling the truth about the sexual abuse, ${ }^{121}$ or that the symptoms "were in fact caused by sexual abuse." 22 Thus, in essence, the Alberico court found PTSD testimony scientifically valid, but admissible only for a specializedknowledge purpose.

In the Alberico court's analysis, scientific knowledge swallowed up other categories of expert testimony under Rule 702, subsuming specialized knowledge so that all expert testimony became subject to the scientific-validity standard. The court explained that "[s]cientific knowledge is what distinguishes Rule 702 expert opinion testimony from Rule 701 lay opinion testimony.... [T] he proponent of expert opinion testimony must show that the expert will assist the trier of fact by conveying scientific knowledge." ${ }^{23}$ Later, the court reiterated that "the proper inquiry under Rule 702 is whether the subject of the expert's testimony is grounded in valid, objective science, that is 'scientific, technical or other specialized knowledge."'124 If this analysis were correct, of course, the experts in Locascio (FBI agent) and Johnson (drug offense coconspirator) would have had to show that their evidence was "derived by the scientific method." The court thus could not have admitted the testimony as specialized knowledge for the pur-

116. Id. at 208. Rape Trauma Syndrome (RTS), on the other hand, was not listed in the DSM III$R$. Id. at 195. Therefore, the court held that testimony about RTS should have been excluded, even though there was evidence in the record that RTS was generally accepted by psychologists. Id. at 212; see Krista L. Duncan, Note, "Lies, Damned Lies, and Statistics"? Psychological Syndronte Evidence in the Courtroom After Daubert, 71 IND. L.J. 753, 762 n.92 (criticizing the Alberico court for not taking into account the DSM III-R listing of rape as potential stressor for PTSD).

117. Alberico, 861 P.2d at 209.

118. Id. at 210-11.

119. State v. Lucero, 863 P.2d 1071, 1075 (N.M. 1993) (explaining holding in Alberico).

120. Alberico, 861 P.2d at 208-10.

121. Id. at $210-11$.

122. Id. at 212 .

123. Id. at 202.

124. Id. at 204; cf. Daubert, 509 U.S. at $590 \mathrm{n} .8$ (distinguishing scientific expertise from technical and other specialized knowledge, and stating that Court considered only the admissibility of scientific expertise, not technical or specialized knowledge). 
poses it viewed as appropriate; instead, it would have had to admit the testimony as scientific knowledge and then limit it to a specializedknowledge use.

Alberico was quickly followed by several other cases adopting a similar approach: these courts found psychological syndrome evidence scientifically valid, then limited it to a specialized-knowledge use. In State v. Foret, ${ }^{125}$ the Louisiana Supreme Court adopted Daubert as governing admissibility of scientific expert testimony under Lousiana's Rule $702 .^{126}$ Foret reversed a conviction of attempted child molestation on the grounds that testimony by a child psychologist was erroneously admitted; his testimony that he had examined the victim and concluded that she was telling the truth about having been abused, usiug CSAAS as a diagnostic tool, should have been excluded. ${ }^{127}$ In applying the Daubert factors, the court first accepted that the testimony amounted to "scientific" evidence since it was "based upon the science of chinical psychology and psychodynamic theory." 228 The court found the testimony inadmissible because CSAAS was not generally accepted as a diagnostic tool, untestable, and had an error rate that, to the extent it was known, was unacceptable. ${ }^{129}$

Meanwhile, the New Hampshire Supreme Court, in State $v$. Cressey, ${ }^{130}$ rejected the distinction between testimony that behavior is "consistent with" a person having been abused (or consistent with the behavior of persons known to have been abused) and testimony that a person has been abused. In Cressey, the court reversed a conviction where a psychologist had testified that two children's psychological symptoms were "consistent with those of a sexually abused child."131 The expert had used interviews, art therapy, and a dissociative events scale for identifying symptoms of post-traumatic stress in evaluating the children. The court found "use of this vague syinptomology" not sufficiently reliable for scientific testimony. ${ }^{132}$

In reaching this result, the court found that there was "no appreciable difference" between a statement that "the children exhibited symptoms consistent with those of sexually abused children ... and a statement that, in her opinion, the children were sexually abused."133

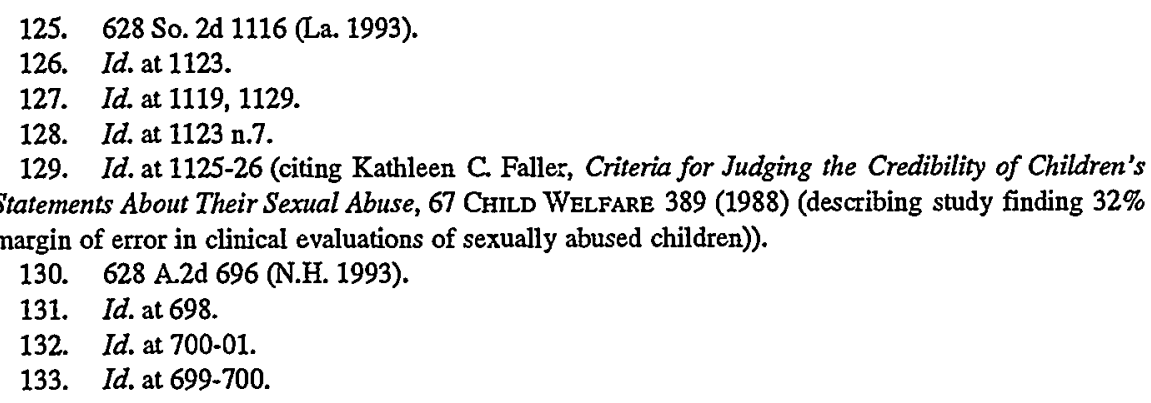


The difference that the court failed to recognize is that one statement compares behaviors that the expert has observed in his or her experience in the field and that have been documented by others in the fielda specialized-knowledge-type statement-while the other statement proposes an explanative theory with diagnostic powers-the ability to conclude with certainty, or to a definable degree of certainty, that certain events or agents caused certain symptoms. The "consistent with" statement recognizes the untestability and unquantifiable error rate of the technique and emphasizes the expert's personal observation.

Indeed, the specialized-knowledge components of personal experience and observation were what most troubled the Cressey court. The court was particularly concerned that the expert's opinion about consistent behavior was based on "her interpretation and evaluation of the available information," especially because "this final interpretive step takes place in [the expert's] mind, drawing on her experiences and personal knowledge."134 Of course, this contribution of experience and personal knowledge, set out for the trier of fact, is exactly what a specialized-knowledge expert is supposed to provide. Since the court incorrectly applied the Daubert test even though the testimony did not involve scientific knowledge, however, this "unverifiable" step in the expert's evaluation contributed to disqualifying the testimony. ${ }^{135}$

Finally, in Isely v. Capuchin Province, ${ }^{136}$ the plaintiff alleged having repressed a period of sexual abuse and proposed to have his treating therapist, Dr. Hartman, testify as an expert in the area of PTSD and repressed memory. ${ }^{137}$ The defendants moved to exclude any testimony regarding repressed memory on the grounds of lack of scientific validity, and to preclude the therapist from testifying to the truth of the plaintiff's allegations of sexual abuse. ${ }^{138}$ Citing Alberico, ${ }^{139}$ the court focused particularly on the factors of whether the theory can be or has been tested, "whether the theory has been proven out or not proven out under clinical tests or some other accepted procedure for bearing it out," and whether the theory has been subjected to peer review. ${ }^{140}$ For the Isely court, these factors were subsumed into their version of a "general acceptance" test. "In other words, in the context of this case, the witness must be able to show, through the use of reliable, viable extrinsic evidence, whether repressed memory or post-traumatic stress disorder is a theory that is accepted in the field of psychology, and if so, to

134. Id. at 701.

135. Id.

136. 877 F. Supp. 1055 (E.D. Mich. 1995).

137. Id. at 1056-57.

138. Id.

139. Id. at $1060-62$.

140. Id. at 1064. 
what extent."141 After establishing her qualifications, the expert testified that many articles she had authored on PTSD and repressed memory had been subjected to peer review. Regarding PTSD, she testified that the committee that developed the diagnostic criteria for PTSD in the $D S M I I I-R$ and $D S M I V$, on which she had served, had "sent the criteria out to the psychological community for clinical testing." 142 'Regarding repressed memory, the expert testified that although repressed memory cannot be empirically tested, studies had documented the phenomenon, including one in which forty percent of survey respondents who reported having been abused as children also reported "a period of not remembering part of the abuse." ${ }^{143}$ Dr. Hartman had personally worked with numerous patients whom she considered to have experienced repressed memory. She also said that the concept of repressed memory has "a fair degree of acceptance in the field" of psychology..$^{144}$

The Isely court concluded that the surveys Dr. Hartman described had "validated the theory of repressed memory," and that

[w] hether other experts agree with the theory or not, because there is no absolute einpirical way to prove that (1) an event happened and/or (2) that the memory of it was repressed, it will be up to the jury to determine the probative value of Dr. Hartman's opinion. In the Court's view, there is a sufficient scientific basis of support for the theory in Dr. Hartman's field of expertise, through the studies and writings, to permit the issue to go to the jury. ${ }^{145}$

However, the court permitted the expert to testify only to her theories and opmions about PTSD and repressed memory and to her opinion that Isely's behavior was consistent with that of persons suffering from these conditions or who have suffered sexual abuse. The court refused to permit the expert to testify that she believed the plaintiff's allegations, because "[s]uch testimony would invade the province of the jury by vouching for the credibility of Isely." 146 Thus, the Isely court shoehorned repressed memory testimony into admissibility within the Daubert scientific-knowledge framework by ignoring the error-rate factor and elevating the self-reporting of survey responses to the level of scientific testing. Next, the court limited the expert's testimony to the

141. Id.

142. Id. at 1065 .

143. Id.

144. Id.

145. Id. at 1066; see Cynthia V. McAlister, Comment, The Repressed Memory Phenomenon: Are Recovered Memories Scientifically Valid Evidence Under Daubert?, 22 N.C. CENT. L.J. 56, 78-79 (1996) (critiquing Isely).

146. Isely, 877 F. Supp. at 1067. 
functional parameters of specialized-knowledge evidence by refusing to permit her to testify that her observations proved that the plaintiff's allegations were true. The court could have avoided this circuitous approach by simply rejecting the testimony for scientific-knowledge purposes and admitting the appropriate portions for specializedknowledge purposes.

The issue of the applicability of Daubert to expert testimony by psychologists has also arisen in the area of testimony on factors affecting eyewitness identification. In Rincon $v$. United States, ${ }^{147}$ the Supreme Court remanded for reconsideration in light of Daubert a case involving expert testimony on eyewitness identification. The district court in Rincon had rejected the proffered testimony of an experimental psychologist who would have discussed the phases of eyewitness identification, the effect of various psychological factors on each phase, and empirical evidence contradicting lay assumptions about eyewitness identification. ${ }^{148}$ The expert would not have offered an opinion about the accuracy of the eyewitness identifications in the case. ${ }^{149}$ The circuit court affirmed, holding that the proffered testimony failed to conform to a "generally accepted explanatory theory"150 and that it would not assist the jury. ${ }^{151}$ On remand, the district court again rejected the evidence, ruling that the testimony would not assist the jury, did not relate to an area recognized as a science, and was likely to confuse the jury. ${ }^{152}$ The Ninth Circuit again affirmed, reciting the Daubert factors and concluding that the defendant had not submitted sufficient information for the district court to be able to conclude that the proposed testimony was "on a 'scientific subject."'153

However, the courts in Rincon would have done better had they begun by assessing the function of the proposed testimony. The expert did not propose to apply an explanative theory to reach a conclusion about the facts in the case, such as by offering an opinion on the accuracy of the identifications at issue. Rather, she proposed to testify about what her experience and training in the study of memory demonstrated about eyewitness identification in general. The courts should have recognized that this testimony functioned as specialized knowledge, and evaluated it under the standard of helpfulness to the jury.

147. 510 U.S. 801 (1993) (mem.).

148. See Rincon v. United States, 984 F.2d 1003, 1004 (9th Cir. 1993).

149. See id.

150. Id. at 1005 (quoting United States v. Christophe, 833 F.2d 1296, 1299-1300 (9th Cir. 1987)) (internal quotation marks omitted).

151. Id. at 1006.

152. United States v. Rincon (Rincon II), 28 F.3d 921, 923 (9th Cir. 1994).

153. Jd. at 924-25. 


\section{Failure to Distinguish Scientific-and Specialized-Knowledge Uses Undermines the Daubert Test}

The state and federal court decisions discussed in the previous section purported to apply the Daubert analysis, but manipulated it to admit testimony that, as presented, could not clear the scientific validity hurdle. In other words, the evidence either failed the Daubert test but, instead of being rejected, came in anyway in a limited form; or passed the Daubert test but, instead of being admitted fully, came in only in a limited form. These results are explicable only if one recognizes the missing step: the courts found the evidence inadmissible for a scientific purpose, recast the evidence as specialized knowledge, and found it admissible in that form.

Some courts implicitly or explicitly realize that their concern is with the purpose or function for which the testimony is offered. For example, the New Mexico Supreme Court in State v. Lucero, ${ }^{154}$ in reversing a conviction where the expert had testified to credibility, explained that "[w]here the state went wrong in this case was in the purpose for which it offered [the expert's] testimony."155 In Gier $v$. Educational Service Unit No. $16,{ }^{156}$ the district court held that the plaintiffs "failed to demonstrate... that their experts' methodologies ... are reliable for the investigative purposes [for which] plaintiffs now seek to use them."157 However, these courts still failed.to recognize that they were rejecting the evidence as scientific-knowledge evidence but accepting it as specialized-knowledge evidence.

The scientific-knowledge use of expert psychological testimony occurs when an expert uses a diagnosis such as PTSD-a catalogue of observable symptoms-as an explanative theory to deduce the occurrence of an event. This includes testimony such as that in the Marquez trial, where the psychologist gave testimony to the effect that because he had observed certain symptoms in the victim, he could conclude that she had been sexually abused. ${ }^{158}$ Psychological syndrome evidence offered for this function should be rejected under the Daubert test due to its inability to be empirically verified and its unknown rate of error. ${ }^{159}$

The specialized-knowledge use of expert psychological testimony occurs when an expert relies on personal experience with sexual abuse victims and a knowledge of the literature in the field to conclude that the symptoms he or she has observed in the victim are similar to, or con-

154. 863 P.2d 1071 (N.M. 1993).

155. Id. at 1076.

156. 845 F. Supp. 1343 (D. Neb. 1994).

157. Id. at 1353.

158. See State v. Alberico, 861 P.2d 192, 197 (N.M. 1993).

159. See supra notes $97-103$ and accompanying text. 
sistent with, those observed in known victims of abuse. When the testimony functions in this way, it is comparative and impressionisticunlikely to overawe a jury with its "aura of infallibility." A court may determine that this use of the evidence may educate a jury about the issues in the case or refute commonly held but erroneous assumptions about the issues. Such testimony operates in the same way as that of the specialized-knowledge experts in cases like the FBI agent in Locascio or the drug offense coconspirator in Johnson. ${ }^{160}$ An expert testifying to specialized knowledge of psychological syndromes should not be permitted to offer an opinion about the truthfulness of the victim, since such testimony would engage an explanative theory and thus function as scientific-knowledge testimony. The post-Daubert psychological syndrome cases discussed above fail to recognize the distinctions between the respective functions of scientific- and specialized-knowledge expert testimony. Thus, these courts distort the Daubert test and undermine its usefulness by admitting evidence for a specializedknowledge function under the rubric of scientific-knowledge evidence.

What is at stake in this distinction is the utility of admissibility standards designed to provide additional screening for scientific expert testimony. If we accept the notion that scientific evidence raises concerns about overawing the jury, overwhelming it with esoteric technical information, or usurping its function of assessing credibility, so that special safeguards are needed to ensure such evidence is reliable, ${ }^{161}$ then we need a coherent and predictable basis for applying the higher level of scrutiny. Finding this basis is the challenge. Expert testimony is really a spectrum, with specialized knowledge at one end and science at the other. At the middle, the distinction between the two can be hard to draw.

One commentator arguing for a separate standard for specialized knowledge describes how "ultimately all types of expert knowledge are inferences from underlying experience," but suggests that "the epistemology of nonscientific expert knowledge is quite different from that of scientific propositions."162 Other commentators reject altogether the notion that different types of expert opinion testimony require different levels of screening. ${ }^{163}$ Nonetheless, the idea that courts should be more suspicious of testimony based on science than of that based on experi-

160. See supra notes 55-63 and accompanying text.

161. See supra notes $80-96$ and accompanying text (discussing truthfulness determinations and debate over whether science overawes juries).

162. Imwinkelried, supra note 6 , at 2294.

163. See generally Dreyfuss, supra note 92; see also Berger, supra note 20 , at 46 n.5 (reporting that American College of Trial Lawyers suggests extending Daubert's approach to all expert testimony). 
ence or skill has been perhaps universally accepted by courts at least since the Frye decision.

In order for a special admissibility standard to protect effectively the concerns raised by scientific expert testimony and not by other expert testimony, we need a consistent way to distinguish what testimony raises these concerns. In the cases I describe in the preceding section, courts admitted evidence under the scientific-validity standard that was not based on the scientific method as contemplated by Daubert-for example, testimony that an alleged child sexual abuse victim's behavior was consistent with that of known victims. The courts admitted this evidence because it did not implicate the same concerns as testimony that made scientific claims-for example, the claim that the expert could "diagnose" the occurrence of sexual abuse by observing psychological symptoms of the alleged victim. But because the evidence did not engage these concerns, the courts should have examined it under the standard for technical or other specialized knowledge.

When courts expand the standard for scientific evidence to admit evidence that does not meet the standard, this lessens the utility and predictability of the standard. If courts relax the requirement that scientific evidence be "derived by the scientific method" in order to admit this evidence, the standard loses its usefulness for excluding evidence that actually does raise the problems of scientific evidence. Evidence that is based on a scientific theory that cannot be validated may then come in because the requirement of scientific validity is not consistently applied.

A second problem that arises from the failure properly to distinguish scientific- and specialized-knowledge evidence is the problem of the specialized-knowledge standard providing an "escape hatch" for expert testimony that cannot clear the scientific-validity hurdle. ${ }^{164}$ Just as we need a standard to distinguish scientific- and specializedknowledge testimony in order to tell when the scientific-validity test applies, we need a standard to determine when it does not. Litigants should not have the option of declaring that proffered expert testimony does not claim to be scientific and thus is subject only to screening as non-science. Instead, a court must have a basis for determining whether testimony raises concerns about truthfulness determinations or overawing or overwhelming the jury such that it should be tested for scientific validity.

164. See supra note 9; $c f$. Faigman, Evidentiary Status, supra note 6 , at 961 ("Ironically ... psychology might be excludable under Daubert for not being scientific; at the same time, however, its key to admission lies in its not being scientific."). 


\section{IV}

\section{PROPOSED SOLUTION}

A. A Case Applying the Distinction Between Scientific and Specialized Knowledge Evidence (Starzecpyzel)

A decision insightfully recognizing the distinction between the functions of scientific- and specialized-knowledge expert testimony, United States $v$. Starzecpyzel, ${ }^{165}$ deals not with psychological testimony but with testimony dealing with handwriting identification, or "forensic document examination." In Starzecpyzel, a New York federal district court concluded that forensic document examination did not measure up to the Daubert scientific-validity standard, but that the testimony was nonetheless admissible as specialized-knowledge evidence. The prosecution sought to present the testimony of a forensic document examiner that signatures on two documents were not genuine. The defense moved to exclude the testimony or, alternatively, for a Daubert hearing on the testimony, arguing that "[t]his alleged expertise [of forensic document examination] has never been validated as credible scientific or technical knowledge and does not comport with the requirements of evidentiary reliability articulated by the Supreme Court" in Daubert. ${ }^{166}$ The court granted the hearing. The prosecution presented the testimony of the vice president of the American Board of Forensic Document Examiners describing the certification process for document examiners, training of document examiners, and the basic principles of forensic document examination. The defense presented two experts who argued that forensic document examination was not a science. ${ }^{167}$

The court concluded that the testimony of the forensic document examiner was admissible as specialized knowledge.

While the Court originally considered Daubert to be controlling as to the admissibility of the forensic testimony at issue ... the Court now concludes that Daubert, which focuses on the "junk science" problem, is largely irrelevant to the challenged testimony. The Daubert hearing established that forensic document examination, which clothes itself with the trappings of science, does not rest on carefully articulated postulates, does not employ rigorous methodology, and has not convincingly documented the accuracy of its determinations. The Court might well have concluded that forensic document examination constitutes precisely the sort of junk science that Daubert addressed.

Yet, as distinguished from such discredited ventures as hedonic damage expertise, clinical ecology, trauma-cancer expertise or

165. 880 F. Supp. 1027 (S.D.N.Y. 1995).

166. Id. at 1028 (quoting Defendants' Mem. at 1-2) (emphasis added) (alteration in original).

167. Id. at 1031-36. 
the Bendectin plaintiffs' statistical machinations, forensic document examination does involve true expertise, which may prove helpful to a fact-finder. [Forensic document examination] expertise is not properly characterized as scientific, but as practical $\mathrm{m}$ character. In a nutshell, over a period of years, [forensic document examiners] gradually acquire the skill of identifying similarities and differences between groups of handwriting exemplars.... The Court therefore treats forensic document expertise under the "technical, or other specialized knowledge" branch of Rule 702, which is apparently not governed by Daubert. ${ }^{168}$

The Starzecpyzel court determined that forensic document examination had not been tested (though the court believed it could be), that had no known error rate, and that publications in the field lacked "critical self-examination." 169 As to general acceptance, the court found the community of forensic document examiners to be "devoid of financially disinterested parties," making general acceptance within that community irrelevant, while scientists in related "mainstream scientific" fields such as pattern recognition and motor control either were unaware of forensic document examination or were critical of it. ${ }^{770}$

Nonetheless, the court concluded that the forensic document examiner's specialized knowledge could assist the jury. ${ }^{71}$ The court allowed the expert to offer an opinion as to genuineness, and to point out similarities and dissimilarities between the genuine signatures and the alleged forgeries. ${ }^{172}$ However, the court indicated that it might refuse to allow the expert to quantify his or her degree of certainty in the opinion because such a quantification might give the jury an unwarranted impression that the testimony was of a scientific character. ${ }^{173}$

The court's determination that the testimony of an experienced document examiner was admissible as specialized knowledge probably surprised both sides in Starzecpyzel. The defense had argued that the evidence should be excluded altogether because it lacked scientific validity. ${ }^{174}$ The wording of the defense's motion, quoted above, suggests that the defense believed that the scientific validity standard applied to all expert testimony under Rule $702 .{ }^{175}$ The prosecution, while declining to present forensic document examination as "hard science," had attempted to bolster its scientific validity through the testimony of its

168. Id. at 1028-29 (footnotes omitted).

169. Id. at 1038.

170. Id.

171. Id. at 1044-46.

172. Id. at 1045-47.

173. Id. at 1048-50.

174. See id. at 1044 .

175. See id. at 1028. 
expert and by characterizing the field as "a hybrid ... based on scientific principles."176 Thus, neither party recognized the possibility that the court ultimately settled on: admitting the testimony for a specialized-knowledge purpose while precluding the expert from making scientific claims.

The Starzecpyzel court thus reached a result similar to those of many courts considering psychological syndrome evidence: while the expert could testify on the basis of practical experience and training, he or she would not be permitted to draw conclusions based on techniques that did not meet the Daubert standard of scientific validity. However, by matching the standard for admissibility to the purpose for which it admitted the testimony, the Starzecpyzel court maintained the integrity of the Rule 702 standards.

\section{B. A Proposed Test Based on the Function of the Evidence}

I propose that to preserve the integrity of the test for scientific evidence as a tool for ensuring that only scientifically valid testimony is admitted, courts should adopt the Starzecpyzel approach: they should first determine whether proposed testimony functions as scientific or specialized knowledge, and only then assess scientific validity or helpfulness.

The threshold question for courts assessing the admissibility of expert testimony-the question prior to deciding scientific validity or helpfulness to the jury-is which test for admissibility applies. Under my proposal, to identify what evidence is scientific knowledge and what is specialized knowledge, the court should look to the purposes for which each type of evidence is introduced. The evidence is scientific when the expert applies an explanative theory to draw a conclusion about facts in the case, to "predict back"177 to determine causation. A scientific expert provides theoretical expertise. Specialized knowledge, on the other hand, is introduced to provide a descriptive account of information that the expert acquires through experience and training and that is not available as part of the common experience of the trier of fact. Specialized knowledge illuminates the facts in the case by serving as a basis for comparison between those facts and the expert's experience. The specialized-knowledge expert draws on personal experience, training, and skills. The expert may give background information that assists the jury in understanding the facts of the case, or may actually compare the facts to his or her own experience.

Scientific-knowledge evidence is functionally different from specialized-knowledge evidence in that it applies an explanative theory that

176. Id. at 1041.

177. State v. Alberico, 861 P.2d 192, 210 (N.M. 1993). 
operates separately from the experience and knowledge of the expert. The specialized-knowledge expert, on the other hand, recounts experiences and observations in a specialized field and compares this knowledge with the facts of the case.

One might say that the distinction between applying an explanative theory (scientific-knowledge purpose) and drawing a comparison (specialized-knowledge purpose) is impossible to make because every witness who interprets events based on his or her experience is applying a theory. For example, in the Markum case described in Part $\Pi,{ }^{178}$ the fire chief testified that in his opinion, a fire had been deliberately set. He based his opinion on many years of experience and training as a firefighter. The fire in question had destroyed a house where only hours before the chief and his department had thoroughly extinguished a previous fire. It could be said that the fire chief in Markum applied a theory: fires that have been extinguished do not quickly rekindle into conflagrations. This statement would be true in the sense that human experience is a constant process of forming, testing, and adjusting hypotheses about the world. However, for purposes of the functional test I understand an "explanative theory" to mean a theory that operates independently of the expert's own experience.

Professors Walker and Monahan's description of "social frameworks"179 is useful for distinguishing a scientific-knowledge purpose from a specialized-knowledge purpose. The concept of a social framework closely parallels my understanding of scientific testimony as the application of an explanative theory to the facts of the case. According to Walker and Monahan, a court employs social science as a social framework when it decides issues of fact specific to the case before it with reference to social science research conducted outside the context of the specific parties and issues in the case. ${ }^{180}$ In the creation of social frameworks, "general research results are used to construct a frame of reference or background context for deciding factual issues crucial to the resolution of a specific case."181

As examples of the use of social framework evidence, Walker and Monahan cite testimony concerning eyewitness identification, statistical predictions of dangerousness at a penalty trial, battered woman syndrome, and the characteristics of sexually abused children. ${ }^{182}$ They note

178. See supra notes $64-71$ and accompanying text.

179. Laurens Waiker \& John Monahan, Social Frameworks: A New Use of Social Science in Law, 73 VA. L. Rev. 559, 559 (1987).

180. See id. at 558-59.

181. Id. at 559 .

182. Id. at 563-67. One text distinguishes framework evidence from syndrome evidence. It states that "framework" best describes social science evidence that "relates to social or familial settings similar to those in which the events in suit occurred but rests largely on case studies unrelated 
that the most problems arise when social frameworks present "information... derived from studying groups of people who are claimed to be similar in certain key respects to one of the immediate parties," 183 and this evidence is offered to prove past behavior. Predictions of future behavior, such as an economist's testimony about probable future earnings, are generally not seen as problematic. ${ }^{184}$ "Since future acts have not yet occurred, it is easy to understand how estimates derived from group data of the likelihood that future acts will occur are acceptable in the law."185 The authors conclude that this distinction between assessing the probability of future events and past events should have no bearing on the admissibility of social frameworks. For purposes of the functional test, this position is also correct: it is the application of an explanative theory, not whether the facts to which it is applied are past or future, that should determine whether testimony is deemed to be scientific or specialized in nature.

In other words, social science evidence, such as psychological syndrome evidence, functions like scientific evidence when used as a social framework. When general research is used to decide a case-specific factual issue, it is presented as an explanative theory that can be applied to draw conclusions about the facts in the case. In this view, Walker and Monahan's formulation sheds light on the functional distinction between evidence that should be subject to the Daubert test and evidence that should be treated as specialized knowledge.

\section{Paradigms of Scientific-Knowledge and Specialized-Knowledge Testimony}

To further illustrate the functional distinction, I will set out paradigms of these two categories of expert testimony. The paradigms describe hypothetical testimony regarding the psychological symptoms of child sexual abuse victims. As I discuss in detail below, this type of testimony commonly presents courts with the characterization problems that this Comment attempts to resolve.

The psychological testimony I describe straddles a line between testimony that is functionally scientific knowledge and testimony that is functionally specialized knowledge. At one extreme are those forms of expert testimony where the expert's opinion is the theory: for example, in Daubert, the theory that the drug Bendectin causes birth defects.

to those events." Christopher B. MUeller \& Laird C. KIRKPatrick, Evidence UNDER the RULES 729-30 (1995). "Syndrome evidence" combines such research studies with studies of and interviews with the particular persons in the case. See id. This categorization appears to distinguish between an expert who has interviewed a person in the case and one who has not.

183. Walker \& Monahan, supra note 179 , at 572-73.

184. See id. at 573 .

185. Id. 
This testimony cannot function like specialized-knowledge evidence and yet be useful to the jury, because the incidence of birth defects is too small and their causes are too elusive for an expert's practical experience-for example, in treating children with birth defects- to be helpful to the jury. At the other extreme are those forms of testimony so specific to the expert's personal experience that it is hard to imagine how they could be offered to the jury in the form of a theory. An example is the security officer's testimony in Chappell, discussed in Part $I_{1}{ }^{186}$ in which the expert opined that checks were counterfeit, based on his years of experience as a security officer at the bank on which the checks in question were purported to be drawn. However, in some cases, expert testimony by psychological experts, particularly in child sexual abuse prosecutions, may function in either manner, as the following paradigms demonstrate. ${ }^{187}$

Imagine a child sexual abuse prosecution in which the state offers the testimony of two experts, Expert $A$ and Expert $B$. Both are clinical psychologists qualified as experts by their training and experience in working with sexual abuse victims. Both have interviewed the alleged victim. Expert $A$ will testify based on her knowledge of one or more psychological theories such as child sexual abuse accommodation syndrome (CSAAS), post-traumatic stress disorder (PTSD), and statement validation techniques. ${ }^{188}$ She will testify that the alleged victim suffers from nightmares, has difficulty concentrating, and has lost interest in significant activities. ${ }^{189}$ She will state that these symptoms indicate that the child suffers from PTSD, an established psychiatric diagnosis described in the $D S M I I I-R .^{190}$ She will further testify that she has observed these symptoms in known victims of sexual abuse, ${ }^{191}$ and that by observing the alleged victim's symptoms, she has formed an opinion as to the traumatic event that caused the disorder. ${ }^{192}$ She will state that in her opinion, there is a ninety percent certainty that the alleged victim suffers from PTSD resulting from sexual abuse.

Expert $B$ will also testify based on her knowledge of psychological theories and her experience working with victims of child sexual abuse.

186. See supra notes $72-76$ and accompanying text.

187. Only the recognition that expert psychological testimony may function as either scientificknowledge or specialized-knowledge evidence can account for the decisions of several courts that have applied the Daubert standard to this type of evidence. See supra Part III.C.

188. See Askowitz \& Graham, supra note 51, at 2036-63 (discussing these theories). Askowitz and Graham describe one problem with expert psychological testimony in these cases: experts apply a "whole package" approach involving aspects of PTSD, CSAAS, and statement validation, and fail to identify or explam the theoretical bases of their opinions. See id. at 2063-69.

189. See id. at $2045 \mathrm{n} .88$ (noting diagnostic criteria for PTSD from DSM III-R).

190. See, e.g., State v. Alberico, 861 P.2d 192, 208 (N.M. 1993).

191. See, e.g., Askowitz \& Graham, supra note 51, at 2047.

192. See, e.g., Alberico, 861 P.2d at 195-97, 208. 
She will describe her observations of the psychological symptoms presented by known sexual abuse victims and the alleged victim's psychological symptoms. She will state that the child's symptoms are consistent with those she has observed in known sexual abuse victims with whom she has worked and with symptoms of known sexual abuse victims documented in the psychological literature.

Expert $A$ 's testimony should be evaluated as scientific knowledge and rejected under the scientific-validity standard; Expert $B$ 's testimony should be evaluated as specialized knowledge and admitted as helpful to the jury. Expert $A$ 's testimony is offered for a scientific purpose because it purports to apply an objective theory that produces consistent results. This theory is separate from and independent of the expert's own experience. That is, Expert $A$ claims that the diagnostic criteria for PTSD operate like a test that produces the same results from the same facts when applied by any qualified expert -an almost mechanical result like that of a chemical test to determine the composition of a substance. Expert $B$ 's testimony describes the experience that forms the basis of her conclusion, and asks the jury to assess her comparison.

Although both experts' testimony concerns the same discipline, psychology, each expert's testimony functions differently in the way the knowledge is presented. Expert $A$ is asking the jury to accept the validity of what she claims is a technique for diagnosing the occurrence of sexual abuse, and to apply this theory to the facts of the case. Expert $B$ is asking the jury to compare her experience and the experience of others in her field to the facts of the case.

In a case such as Daubert, an Expert $B$-type comparison would not be possible. To illustrate, imagine the Daubert plaintiffs offering the testimony of a pediatrician whose opinion that Bendectin had caused the plaintiffs' birth defects was based on her many years of experience in treating children with birth defects. Like a psychologist testifying in a child sexual abuse prosecution, might not this expert say that she had treated many children with birth defects and that the plaintiffs' birth defects were consistent with birth defects caused by Bendectin? No, because the expert would have no basis for comparison. As "[t]he record in [Daubert] categorically refutes the notion that anyone can tell what caused the birth defects in any given case," 193 the expert would not be able to compare the plaintiffs with children with birth defects known to have been caused by Bendectin.

A specialized-knowledge expert who offers a "consistent with" opinion is presumably comparing his or her observations in the particular case with observations in cases where the fact at issue was established. For example, the psychologist in the child sexual abuse case is

193. Daubert II, 43 F.3d at 1320 n.12. 
(at least implicitly) comparing the behavior of the alleged victim with that of children who are known to have been abused. The expert who testifies that the defendants' behavior indicates they are part of an organized crime family ${ }^{194}$ presumably is comparing the defendants to persons who have been convicted of involvement in organized crime. A "consistent with" opinion must always assume an objectively verifiable basis of comparison. Otherwise, the expert psychologist would simply be testifying that "this child's behavior is consistent with that of children whom I believed to have been abused." Such a comparison would not be helpful to the fact finder.

\section{CONCLUSION}

Courts and commentators grappling with the problem of how to categorize expert testimony after Daubert have attempted a variety of solutions. For example, one court relied on a kind of general acceptance standard for determining whether testimony is scientific: "Daubert may... be viewed as establishing reliability standards for expert testimony in fields whose scientific character is undisputed." 195 Another court apparently rested its determination on the representations of the proffering party: "[defendant] argues that the proffered testimony constitutes scientific knowledge. Thus, as in Daubert, we limit our discussion to the 'scientific knowledge' aspect of Rule 702 . .."196

In assessing psychological evidence, some commentators have assumed that the scientific-validity standard applies to all evidence related to a particular psychological syndrome, but have argued that the evidence is admissible. ${ }^{197}$ This approach is similar to that of the decisions described in Part II.C, which bent the requirements of scientific validity under Daubert in order to admit expert testimony that functioned like specialized knowledge. Askowitz and Graham take an opposite approach, concluding that because some psychological theories cannot be subjected to empirical testing, Daubert's scientific-validity requirement does not apply to expert psychological testimony based on these theories. ${ }^{198}$ In other words, because this testimony can never meet the

194. See supra notes 59-63 and accompanying text (discussing Locascio).

195. United States v. Starzecpyzel, 880 F. Supp. 1027, 1039 (S.D.N.Y. 1995).

196. United States v. Rincon (Rincon II), 28 F.3d 921, 923-24 n.3 (9th Cir. 1994).

197. See A. Renee Callahan, Will the "Real" Battered Woman Please Stand Up? In Search of a Realistic Legal Definition of Battered Woman Syndrome, 3 AM. U. J. GENDER \& L. 117, 135-41 (1994) (arguing that despite absence of information about rates of error or standards of application, evidence regarding new "survivor theory" should be admitted under Daubert); Melanie F. Griffith, Battered Woman Syndrome: A Tool for Batterers?, 64 FordhaM L. Rev. 141, 194 n.300 (1995) (stating that the "survivor theory" explaining the behavior of battered women will have to meet the Daubert standard).

198. Askowitz \& Graham, supra note 51, at 2097. Askowitz and Graham conclude that 
Daubert requirements of testability and quantifiable error rate, these requirements must not govern its admissibility. Under this circular approach, the Daubert decision becomes redundant because only proffered testimony that can pass its scientific-validity test is subject to that test, while testimony that cannot pass the test is not subject to it. But surely the decision should be understood to have some effect on the admissibility of proffered scientific expert testimony. None of these approaches addresses the question of what brings expert testimony into the ambit of the Daubert test.

The Daubert decision attempted to resolve confusion about the appropriate standard for the admissibility of scientific evidence under the Federal Rules. ${ }^{199}$ However, in so doing, it opened up a new set of questions by creating a separate, complex test for scientific, as opposed to technical or specialized, expert testimony. The Court defined a new standard for admissibility, but neglected to define adequately the evidence to which it applies. Unlike testimony about teratology or DNA identification, which will always function as scientific knowledge, and testimony about law enforcement officers' knowledge of criminal behavior, which will always concern specialized knowledge, some evidence from the field of psychology can fit into either category depending on how the testimony functions.

Courts assessing psychological syndrome evidence after Daubert have confused the inquiry by adjusting the test to exclude aspects of the testimony that function as scientific knowledge (but do not meet the requirement of scientific validity), while admitting aspects of the testimony that function as specialized knowledge. In effect, these decisions have expanded the scope of the Daubert standard to cover all expert testimony by admitting specialized knowledge under a test developed to address the special problems of scientific evidence. In order to preserve the imtegrity of the Daubert test as a tool for ensuring that only scientific testimony that meets the validity standard is admitted, courts should first determine whether proposed testimony functions as scientific or specialized knowledge, and only then assess scientific validity or helpfulness.

[t]he Supreme Court in Daubert reminded trial judges of their obligation to ensure the reliability of "scientific" evidence admitted in their courtrooms. "Scientific" evidence contemplated by the Court in Daubert is an explanative theory incorporating a process capable of being tested to produce error rates. Because this kind of testing is impossible in the field of child sexual abuse, Daubert does not control the admissibility of expert psychological testimony offered in child sexual abuse prosecutions.

Id. Thus, Askowitz and Graham transmute testing, one of the Daubert factors for admissibility, into a factor governing applicability of the Daubert test.

199. See Daubert, 509 U.S. at 585 (describing division among courts over proper standard for admission of expert testimony). 